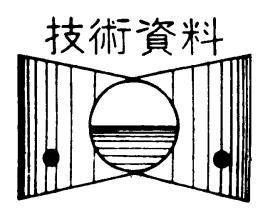

\title{
最近の就航中タービン船における 重大故障についで
}

\author{
西川栄一**宮武

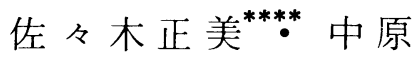 \\ 忠勝 ${ }^{* * *}$ \\ 袥 $^{* * * * *}$
}

On the Serious Failures of the Turbine Ships Launched about 1972, 1973

By Eiichi Nishikawa, Tadakatsu Miyatake, Masami Sasaki, Yusuke Nakahara

For the guide to improve the ship propulsion system reliability, MESJ Boiler Committee collected the failure data occurred in 15 turbine ships launched about 1972, 1973 under the help of those ship's owners. According to the analysis of those data, this report presents the statistical and physical characteristics of serious failures troubled above turbine ships. As for the statistical characteristics, mean failure time is 9.6 hours which is shortened with the comparison of 10.45, 15.6 hours of the ships launched about 1966, 1967. MTBF is 3717 hours, which is longer than 1547 and 1200 hours of those ships launched about 1966, 1967 and about 1969, respectively. Therefore mean availability is fairly improved to 0.9975 . The $56 \%$ of the total failures has occurred in the boiler systems, being most responsible for the propulsion system reliability. The turbine systems have a minor responsibility for the failure occurrence, but their mean failure time is the longest of 22 hours. As for the physical characteristics, the leakage failure is most important, which occurred in any equipment of the propulsion system. Among the equipments composing the boiler system mechanical failures of GAH and leakage failures of FWC should be paid attention. GAH and FWC failures are apt to break down the total propulsion system. The turbine system were troubled mainly by the failures due to the defects of lubricating equipments and due to the vibration events of components.

\section{1. 緒言}

船舶機関系統の信頼性向上の要請は, 自動化の進展, 乗組員数削堿という動向も関連して, 最近ますます強く なってきている．乙のため，現在各方面で信頼性に関す るデータの収集が行われつつある.いうまであなく，信 頼性向上策を講ずるうえで, かかる故障データの堆積は まず取り組むべき作業であるが，現状はまだ十分とはい い難い、そこで, 日本舶用機関学会ボイラ研究委員会で, タービン船を対象に故障データを収集分析するととが企 画された．本稿はその成果の一部，重大故障 (船が減速 または停止に至った故障)に珈わる部分についての報告 である. ての分析の主な目的は次の点にある。一つは故 障の統計的性格, すなわち, 故障のひん度, 規模などを

\footnotetext{
*原稿受付 昭和 54 年 4 月 18 日

** 正会員 神戸商船大学 (神戸市東灘区樑江南町 5-1-1)

*** 正会員 石川島播磨重工業（株）(相生市相生 5292)

****正会員 日本ボイラ協会 (東京都港区芝 5-37-8)

******正会員 三菱重工業 (株) (東京都港区芝 5-34-6)
}

は握するとと，およびそれらを橋本ら ${ }^{123)}$ ，山根ら出の 以前のデータと比較して, 新しい船でどのように変化し ているかを知るとと, 二つは, 故障内容を調べて不信頼 度に責任のある系統や要素を明らかにし，講ずるべき技 術的方策の視点を見いだすととである.

\section{2. 調查方法と範囲}

調査対象は 1977 年時点で就航期間 4 5 年のタービ ン船とし, 船会社へのアンケートで故障データを集める方 法をとった。表 1 はアンケート用紙で, 故障 1 件にての 用紙 1 枚を使ってもらった.

表 2 亿回答が得られた船の要目を示す. 油タンカ 13 隻, コンテナ船 2 隻の計 15 隻である. 表によると出力, 蒸気条件ともほぼ同様で, 昭和 47,48 $(1972,1973)$ 就 航の船が中心になっている. 回答船会社は 4 社である. 回答された各社の重大故障の系統別発生件数は表 3 のよ うである. 全部で 114 件あるが, 表にみるようにその内 訳は船によってかなり異なっている. こてで問題になる のは記録の精度である．故障記録がないとその船は信頼 
表 1 故障記録用アンケート用紙

故障デー夕（故障 1 林につき1枚)

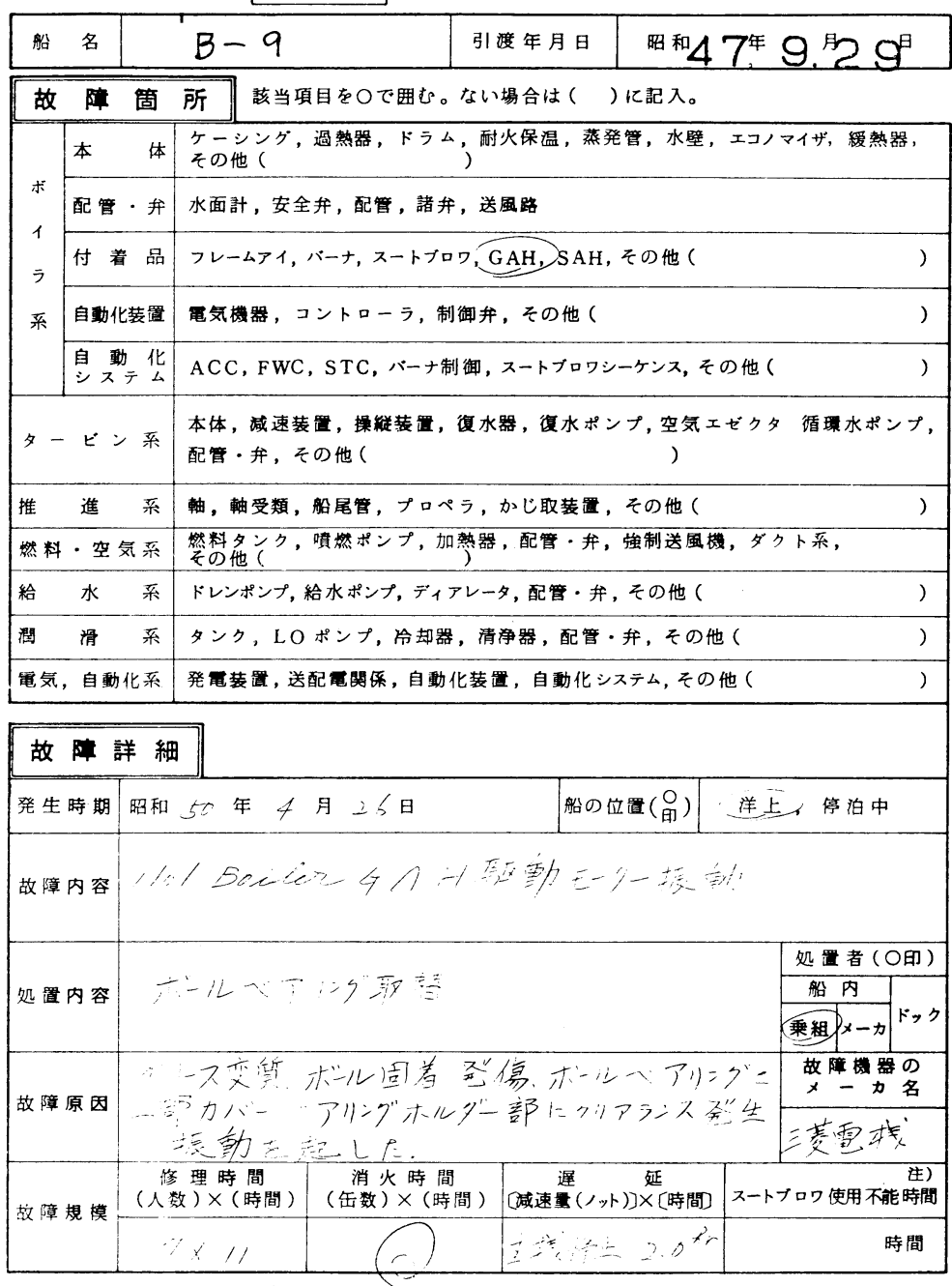

注）スー・トブロの故障のみ記入。

性のたかい船ということになる訳で，その意味で故障を正 確に記録しておくことが重要である.しかし，乙こでは こうした記録の信頼度を判定することはできないので, 船相互の信頼性の比較分析は行わないことにする.

系統別の故障件数の内訳をみるとボイラ系が非常に多 く全体の $56 \%$ 占め，タービン系がこれにつぎ，乙の 2 系統，つまり主機系統で重大故障の $73 \%$ 数えてお り，最む注目すべきサブシステムといえる. アンケート により以上のデータが得られたので, 以下その内容分析 を進めることにする.

\section{3. 発生故障の統計的分析}

表 1 において，(1)主ボイラ消火時間，(2)停止時間，(3) 遅延時間，(4)减速量などは，必ずしもすべて回答されて
いる訳ではなく，(1)だけ記入されていて(2)以下が空白で あったり，(3)が記入されていてあ(4)が空白であったりす るものが相当数あった. それで次のように処理した. (1) だけ記入のあるあのは重大故障とみなし, 消火時間が故 障時間に等しいとした，また，(4)は空白のものが多かっ たので减速度を求めることは控え, 絶対時間でのみ分析 することにした．また，なお各種の平均值を求める場合 は，その計算が可能な回答だけを利用し，全故障に対す る合計数值が必要な場合には，うえの平均值が全体に通 用するとみなして求めることにした。

3.1 故障時間 表 4 亿平均故障時間をしめす. 数 值は停止時間，减速時間一緒にしたもので，後者は減速 度を考慮していない. ボイラ系本体の故障で，ボイラ水 に油分が混入して 40 日間減速したものがあるが，乙れ 
表 2 故障統計アンケート調査回答船要目表

\begin{tabular}{|c|c|c|c|c|c|}
\hline 船 名 & 就航 日 & 調査期間 & 種 類 & DWT & 主 機 ボ イ \\
\hline$A-1$ & 47. 3. 10 & $\begin{array}{c}\text { ５2.4. } 30 \\
\text { (5 年 } 2 \text { 月) }\end{array}$ & コンテナ & 30,800 & $\begin{array}{l}\& 40000 \mathrm{HP} \times 2 \times 135 \mathrm{rpm} \\
135 \mathrm{~T} / \mathrm{H} \times 64 \mathrm{~kg} / \mathrm{cm}^{2} \times 515^{\circ} \mathrm{C}\end{array}$ \\
\hline$A-2$ & 47. 4. 20 & $\begin{array}{l}\sim 52.1 .22 \\
(4 \text { 年 } 9 \text { 月) }\end{array}$ & 鉱 油 船 & 214,400 & $\begin{array}{r}\therefore 30000 \times 1 \times 85 \\
70 \times 61.5 \times 515 \\
\end{array}$ \\
\hline$A-3$ & 47. 9 & $\begin{array}{l}\sim 52.3 \\
(4 \text { 年 } 6 \text { 月 })\end{array}$ & タンカー & 236,800 & $\begin{array}{c}\& 34000 \times 1 \times 90 \\
70 \times 61 \times 515\end{array}$ \\
\hline$A-4$ & 48. 9.28 & $\begin{array}{c}\sim 52.5 .23 \\
\text { (3 年 } 7 \text { 月) }\end{array}$ & タンカー & 233,400 & $\begin{array}{l}\text { IH I } 33000 \times 1 \times 80 \\
69 \times 61.2 \times 515 \\
\end{array}$ \\
\hline$D-5$ & 47. 8. 19 & $\begin{array}{c}\text { ５2. } 4.28 \\
(4 \text { 年 } 7 \text { 月) }\end{array}$ & コンテナ & 45,129 & $\begin{array}{l}45000 \times 1 \times 105 \\
78 \times 62 \times 515\end{array}$ \\
\hline$D-6$ & 48. 7.3 & $\begin{array}{c}\sim 52.5 .3 \\
\text { ( } 3 \text { 年 } 9 \text { 月) }\end{array}$ & 油 槽 船 & 296,337 & $\begin{array}{l}36000 \times 1 \times 90 \\
79 \times 62 \times 513\end{array}$ \\
\hline$B-7$ & 47. 4. 14 & $\begin{array}{l}\text { ５2. } 3.3 \\
(4 \text { 年11月） }\end{array}$ & タンカー & 252,059 & $\begin{array}{l}\text { IH I } 40000 \times 1 \times 84.7 \\
59 \times 61.2 \times 515\end{array}$ \\
\hline B -8 & 47. 6. 21 & $\begin{array}{c}\text { ５2.2.11 } \\
(4 \text { 年 } 7 \text { 月) }\end{array}$ & タンカー & 237,660 & $\begin{array}{l}\text { 日立 } 36000 \times 1 \times 90 \\
55 \times 62 \times 515 \\
\end{array}$ \\
\hline$B-9$ & 47. 9. 29 & $\begin{array}{r}\sim 52.1 .11 \\
(3 \text { 年 } 4 \text { 月 })\end{array}$ & タンカー & 237,093 & $\begin{array}{r}\$ 34000 \times 1 \times 90 \\
53.5 \times 61.5 \times 515 \\
\end{array}$ \\
\hline$B-10$ & 48. 9.4 & $\begin{array}{r}\sim 52.2 .12 \\
(3 \text { 年 } 5 \text { 月) }\end{array}$ & タンカー & 237,307 & $\begin{array}{r}\mathbf{2} 34000 \times 1 \times 90 \\
53.9 \times 61.5 \times 515 \\
\end{array}$ \\
\hline$B-11$ & 49. 3. 5 & $\begin{array}{c}\text { ～} 52.1 .28 \\
\text { ( } 2 \text { 年10月) }\end{array}$ & タンカー & 233,163 & $\begin{array}{l}\text { KHI } 36000 \times 1 \times 90 \\
56 \times 61.5 \times 515\end{array}$ \\
\hline$C-12$ & 48. 7. 3 & $\begin{array}{c}\text { 52. } 7.3 \\
\text { (3年11月) }\end{array}$ & タンカー & 135,444 & $\begin{array}{l}\text { IHI } 40000 \times 1 \times 83 \\
77 \times 75 \times 515\end{array}$ \\
\hline$C-13$ & 48. 9.6 & $\begin{array}{c}\sim 52.6 .20 \\
(3 \text { 年 } 9 \text { 月 })\end{array}$ & タンカー & 231,992 & $\begin{array}{l}\text { KHI } 36000 \times 1 \times 90 \\
72 \times 75 \times 515\end{array}$ \\
\hline$C-14$ & 48. 4. 26 & $\begin{array}{c}\sim 52.8 .10 \\
(4 \text { 年 } 3 \text { 月 })\end{array}$ & タンカー & 231,797 & $\begin{array}{l}\text { KHI } 36000 \times 1 \times 90 \\
72 \times 62 \times 515\end{array}$ \\
\hline$C-15$ & 49. 1. 31 & $\begin{array}{c}\text { ５2.6. } 19 \\
\text { ( } 3 \text { 年 } 5 \text { 月) }\end{array}$ & タンカー & 238,082 & $\begin{array}{l}\text { 日立 } 36000 \times 1 \times 90 \\
72 \times 62 \times 515\end{array}$ \\
\hline
\end{tabular}

表 3 船別, 系統別重大故障件数

\begin{tabular}{|c|c|c|c|c|c|c|c|c|c|c|}
\hline & $\begin{array}{l}\text { ボ } \\
\text { イ }\end{array}$ & $\begin{array}{l}\text { 夕 } \\
1\end{array}$ & 推 & 燃空 & 給 & 潤 & $\begin{array}{c}\text { 電自 } \\
\text { 動 }\end{array}$ & ₹ & \multicolumn{2}{|c|}{ 合 計 } \\
\hline & $\begin{array}{l}\text { ラ } \\
\text { 系 }\end{array}$ & $\begin{array}{l}\text { ビ } \\
\text { ン } \\
\text { 系 }\end{array}$ & $\begin{array}{l}\text { 進 } \\
\text { 系 }\end{array}$ & \begin{tabular}{|l|} 
料気 \\
・系
\end{tabular} & $\begin{array}{l}\text { 水 } \\
\text { 系 }\end{array}$ & \begin{tabular}{|l} 
滑 \\
系 \\
\end{tabular} & $\begin{array}{c}\text { 気化 } \\
\text { - 系 }\end{array}$ & $\begin{array}{l}0 \\
\text { 他 }\end{array}$ & 件数 & 件 / \\
\hline$A-1$ & 4 & & & 2 & & & & & 6 & 0.118 \\
\hline$A-2$ & 10 & 2 & & & & & $2(1)$ & & 14 & 0.261 \\
\hline$A-3$ & 9 & 2 & & & & & & & 11 & 0.217 \\
\hline$A-4$ & 3 & 1 & & & & 2 & & & 6 & 0.144 \\
\hline$D-5$ & 1 & & & & & & & & 1 & 0.022 \\
\hline$D-6$ & & & & & & & & & 0 & \\
\hline$B-7$ & 4 & 2 & & 1 & 2 & & 1 & & 10 & 0.202 \\
\hline$B-8$ & 11 & 5 & & & 1 & 8 & & & 25 & 0.533 \\
\hline$B-9$ & 4 & 2 & & & 2 & & 1 & & 9 & 0.196 \\
\hline$B-10$ & 3 & 1 & 1 & & 2 & & & & 7 & 0.244 \\
\hline$B-11$ & 3 & 1 & & & 1 & 1 & & & 6 & 0.202 \\
\hline$C-12$ & 4 & & 1 & & 2(1) & & & & 7 & 0.156 \\
\hline$C-13$ & & & & & & & & & 0 & \\
\hline$C-14$ & & 2 & & & & 1 & & & 3 & 0.062 \\
\hline$C-15$ & 8 & 1 & & & & & & & 9 & 0.180 \\
\hline 合 件数 & 64 & 19 & 2 & 3 & $10(1)$ & 12 & $4(1)$ & 0 & 114 & 0.214 \\
\hline 計 \% & 56.1 & 16.7 & 1.8 & 2.6 & 8.8 & 10.5 & 3.5 & 0 & 100 & \\
\hline
\end{tabular}

日本舶用機関学会誌 第 14 巻 第 9 号
表 4 重大故障の平均故障時間

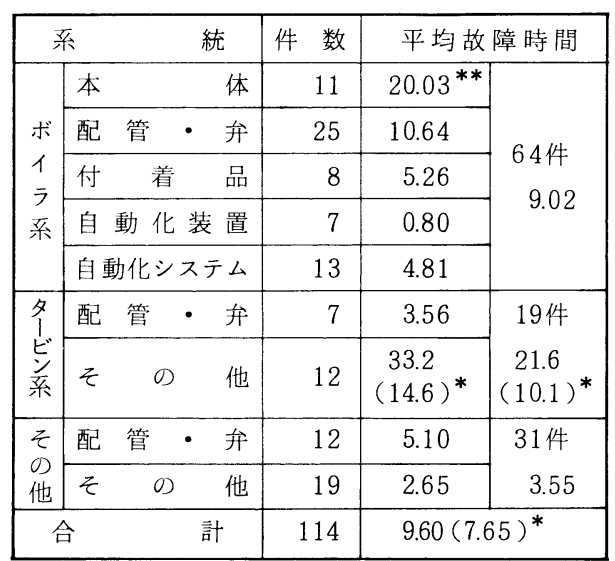

（注） *（）は 1 件 218.7 時間というとびぬけて 大きいのがあるので, それを除外したもの.

**油混入で缶水污染した故障で, 減速 40 日 のあの 1 件あるが, これは除外した. 
は計算から除いてある.全平均時間は 9.6 時間である. 表 をみてタービン系, 抢よびボイラ本体の故障時間の長い のが注目される.タービン系は故障件数では全体の $17 \%$ 程度であるが, 故障時間にすると $38 \%$ をめている. ま た配管・弁類は件数であ 44 件，39\%と大きな部分にな るが, 時間でも全体の $32 \%$ 占めており，機関システ ムの不信頼性に対して重要な責任を有しているといえる.

表 5 は過去の調査との比較である. 橋本 $ら^{1,2)}$ の調査 対象船は 1966, 67 年就航の船が多いが, それらの平均故 障時間 10.45, 15.6 (11.8) 時間と比べると, 今回の 1972,

73 年就航船のそれはやや小さくなっている.

図 1 は 1 件あたりの故障時間の分布をみたものである. 大きな故障にひきずられて平均故障時間は上述のような

表 5 重大故障に関する諸数値の比較

\begin{tabular}{|c|c|c|c|c|c|}
\hline & $\begin{array}{l}\text { 調査対象船 } \\
\text { 就 航 時 期 }\end{array}$ & $\begin{array}{c}\text { 平 均 } \\
\text { アベイラビリティ }\end{array}$ & $\begin{array}{c}\text { MTBF } \\
\text { 時間 }\end{array}$ & $\begin{array}{l}\text { 平均故 障 } \\
\text { MDT* }\end{array}$ & $\begin{array}{l}\text { 時間 } \\
\mathrm{MDT}^{* *}\end{array}$ \\
\hline 橋本 $5^{1)}$ & 平均 1967 & 0.9969 & 1547 & 10.45 & 4.84 \\
\hline "2) & $\begin{array}{c}1965 \sim 1969 \\
1966 \text { 中心 }\end{array}$ & 0.9936 & 1110 & $\begin{array}{c}15.6 \\
(11.8)^{* * * * *}\end{array}$ & 7.11 \\
\hline 山根 $5^{4)}$ & $\begin{array}{l}1965 \sim 1972 \\
\text { 平均 } 1969\end{array}$ & 0.995 & $\sim 1200$ & & 5.5 \\
\hline 今 & $\begin{array}{c}1972 \sim 1974 \\
1973 \text { 中心 }\end{array}$ & 0.9975 & 3717 & $\begin{array}{c}9.60 \\
(7.65)^{* * *}\end{array}$ & \\
\hline
\end{tabular}

(注)

*減速率考慮していない

**減速率考慮している

***（）は長時間の故障 1 件除いた值

****（）は調查期間の長い船（26 ケ月以上）に限った場合

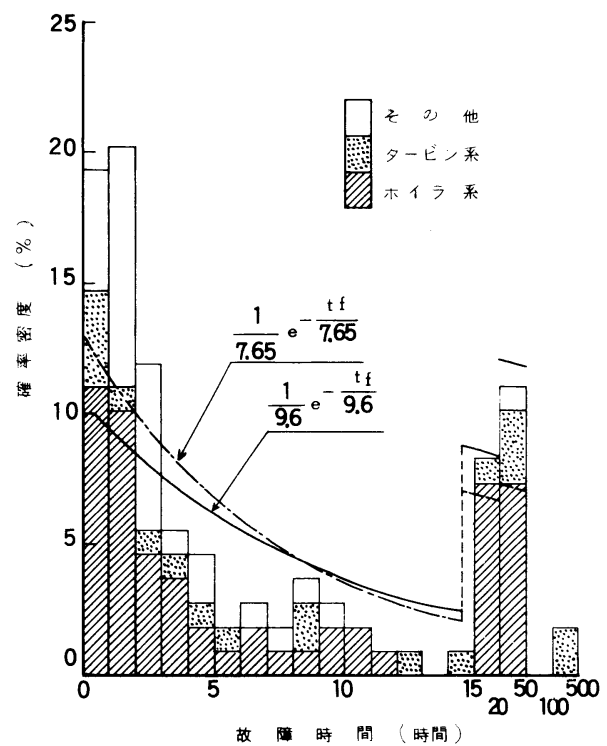

図 1 重大故障時間のひんど分析

（注）——— 1 件 218.7 時間というとびぬけて大きい 故障を除外した場合

油混入による缶水污染のため減速 40 日と いう故障 (1 件) を除外した場合
值になるが, 件数では図のように比較的短時間のあのが 多い. とくにボイラ系, その他の系はそうであり, 全体 として 5 時間以下の故障が $61 \%$ を占める. 図の曲線は 指数分布とみた場合のものであるが，故障時間分布は大 略この分布に従うようで，橋本ら ${ }^{2)}$ と同傾向を示してい る.

3.2 故障発生頻度 図 2 亿就航期間と故障率との 関係を示す. 調査期間 (就航期間に等しい)ほぼ 4 年間で は，故障発生率は就航期間とともに低下しているが，乙 の傾向は系統別にみても，船社別にみても同様である. しかし，1年を過ぎると低下は小さくなるから，乙の点 を強調すればとくにボイラ系, タービン系では, 就航後 1 年で偶発故障期に入るとみることができる. アベイラ ビリティの変化でみると図 3 のようである. 図の值は以 下の定義によっている.

$$
\begin{aligned}
& \text { [アベイラビリティ〕 }=1 \\
& -\frac{\text { [停止故障時間 }+ \text { [减速故障時間 }}{\text { [航海時間 }}
\end{aligned}
$$
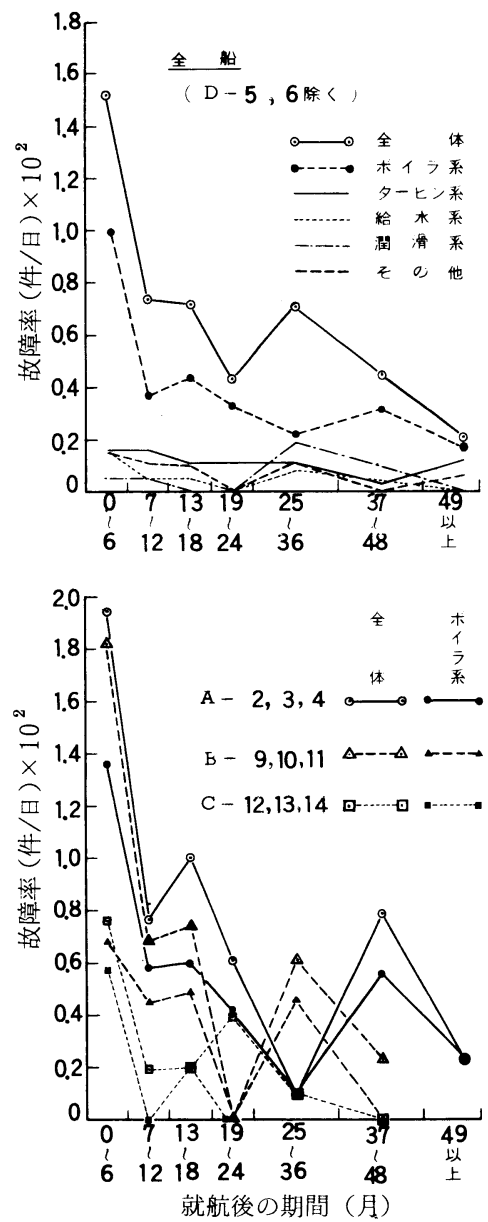

図 2 重大故障率の就航期間による変化 


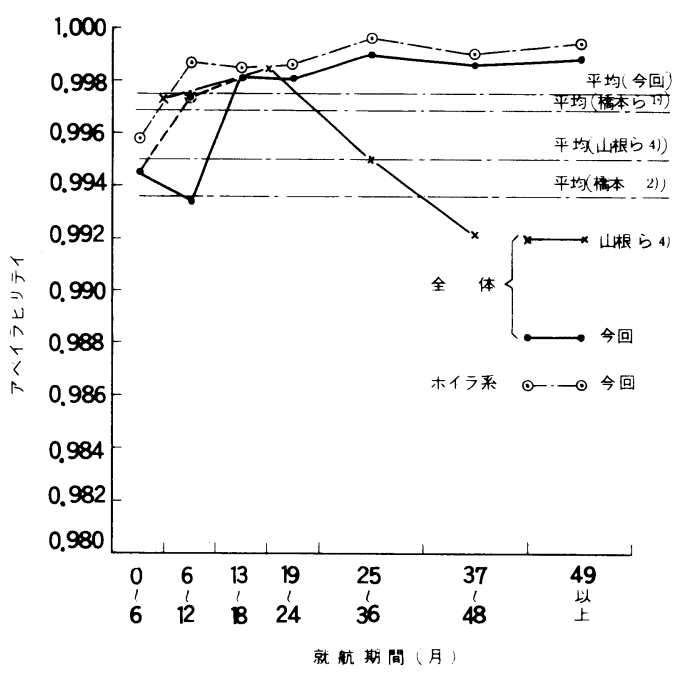

図 3 重大故障時間をむとにしたアベイラビリティ の変化

したがって, 減速率を考慮すればアベイラビリティは図 の值よりも大きくなるはずである．なお，航海時間は， 調査期間から，入きょ時間と入港時間を差し引いた実航 海時間を使用してある.

図によるとアベイラビリティは初期故障期の 1 年をす ぎると 0.998 を越えて格段に上昇し，調査期間 4 年の間 ではその高い水準を保っている. なお, 困の就航期間 0 〜12月で破線でしめした部分は，B-8船の潤滑系で同 一機器 (潤滑油クーラ)に集中している故障 (表 3 参照)を 特異よみて除いた場合の值である. てれを考慮すればア ベイラビリティは全体として上昇していく傾向にあると みれる. 図には橋本ら $ら^{1,2)}\left(1966,67\right.$ 就航船), 山根 $5^{4)}$ (1969 ころ就航船)の值屯並載してあるが, それらと比へ て今回 (1972, 73 就航船) は, 図でみる限りアベイラビ リティはかなり改善されているといえる. とくに就航期 間による変化をみると山根らの場合と大きく異なってい る. 山根らの場合就航後 2 年をすぎるとアベイラビリテ ィは急速に低下し，その主な原因はボイラ系にあった。 しかし, 今回はボイラ系のアベイラビリティも, 調査期 間内では就航期間とよもに上昇しており，逆の傾向を示 している. したがって, 一定の改善がなされてきている といえよう. 以上 3 者のアベイラビリティ, MTBFは表 5 にまとめてある，表によるとMTBF は前 2 者の 3 倍 程度に増大しており，既述のように故障時間も小さくな っているとととあいまって, 結果としてアベイラビリテ ィが上昇したということである.

故障発生箇所の比較を表 6 亿示す. 調査者によって分 類のし方が異なるので共通の比較はできないが*,それで

*調査者によって故障調査の方法や各種定義が異なっている と, 系統的なデータの積み重ねが困難である. この報告で もこの点で正確な比較検討が難しかった. この方面の整備 が望まれる.
表 6 重大故障発生加所の内訳

(a)

\begin{tabular}{|c|c|c|c|}
\hline \multicolumn{2}{|c|}{ 系 統 } & 橋 本 $^{1)}$ & 今 回 \\
\hline \multicolumn{2}{|c|}{ ボイラ 系 } & $17(22.4)$ & $39(34.2)$ \\
\hline \multicolumn{2}{|c|}{ タービン系 } & $11(14.5)$ & $11(9.7)$ \\
\hline \multirow{2}{*}{$\begin{array}{c}\text { そ } \\
\text { の他 }\end{array}$} & 配管・弁 & $17(22.4)$ & $24(21.0)$ \\
\cline { 2 - 4 } & 自動機器 & $17(22.4)$ & $23(20.2)$ \\
\hline \multicolumn{2}{|c|}{ の 他 } & $14(18.3)$ & $17(14.9)$ \\
\hline \multicolumn{2}{|c|}{ 計 } & $76(100)$ & $114(100)$ \\
\hline
\end{tabular}

(b)

\begin{tabular}{|l|r|l|}
\hline 系 統 & 山根 ら & 今 回 \\
\hline ボイラ 系 & $(43.1)$ & $64(56.1)$ \\
\hline タービン系 & $(19.2)$ & $19(16.7)$ \\
\hline その 他 & $(37.7)$ & $31(27.2)$ \\
\hline
\end{tabular}

(注) *（）は\%を示す

**（a ）は橋本らの分類に， ( b ) は山根 らの分類によった場合

あ表で明らかなように，全体に対するボイラ系の比率は 増大している．表には示さないが，ボイラ系は全故障時 間の $54 \% を$ 占めており，全体としてアベイラビリティの 改善はみられるものの, 相対的には重要さを増しつつあ る系統である。

\section{4. 修理実態の統計的分析}

ここでは修理人数 $n_{r}$, 修理時間 $t_{r}$, 修理工数 $n_{r} \cdot t_{r}$ をみる。それらの分布は図 4，平均值は表 7 のようであ る. 図にみるように $t_{r}, n_{r} \cdot t_{r}$ はほぼ指数分布に従う ようであるが, $n_{r}$ の分布は 9,10 人あたりにピークがあ り，9人以上の $n_{r}$ を要した故障が $41 \%$ を占めている. 調 査対象船の機関関係乗組員数は 9 人 2 隻， 10 人 1 隻,

11,12 人各 1 隻, 平均 10.1 人であったから，9人以上 というと事実上全乗組員が修理にかかる必要があったと いうことであり，注目される．適正乗組員数という場合， こうした修理実態も考慮する必要があろう.

平均值をみると故障規模を反映していてやはりタービ ン系が大きい。全体平均は $\overline{n_{r}} 6.5, \overline{t_{r}} 5.0, \overline{n_{r} t_{r}} 36.1$ で あるが, 橋本ら ${ }^{1)}$ の場合それぞれ 8.34, 6.05, 57.1 と比較 すると，いずれあ小さくなっており，修理規模も一定の 改善がなされているといえる.

表 7 重大故障の修理人数 $n_{r}$, 時間 $t_{r}$, 工数 $n_{r} . t_{r}$ の平均值

\begin{tabular}{|l|c|c|c|c|}
\hline & ボイラ系 & タービン系 & その他 & 全 体 \\
\hline$\overline{n_{r}}$ (人) & 6.2 & 8.4 & 5.7 & 6.5 \\
\hline$\overline{t_{r} \text { (時間) }}$ & 5.0 & 8.0 & 3.2 & 5.0 \\
\hline$\overline{n_{r} \cdot t_{r}}$ & 32.8 & 73.6 & 20.0 & 36.1 \\
\hline
\end{tabular}



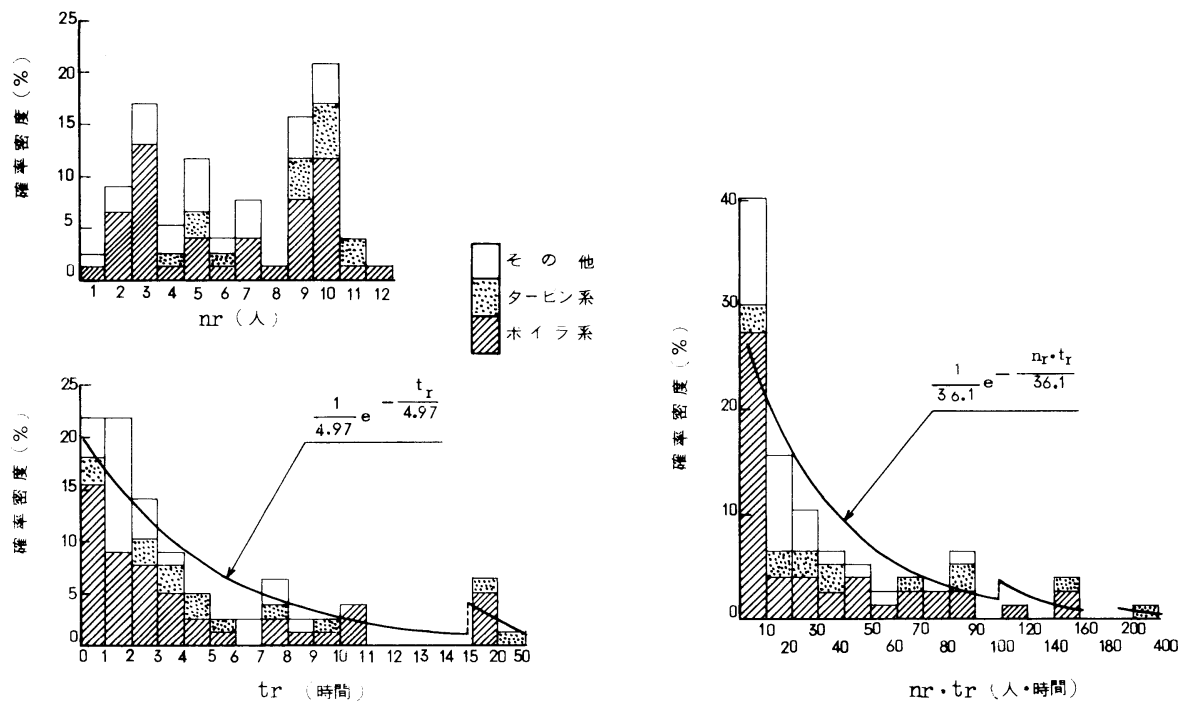

図 4 重大故障の修理人数 $n_{r}$, 時間 $t_{r}$, 工数 $n_{r} . t_{r}$ の分布

\section{5. 故障内容の分析}

5.1 全 般 図 5 は故障発生箇所別に故障事象 (結果) 之故障原因がどう分布しているか，その関係がど うなっているかをみたものである. 図の故障事象で, 漏 えいとはフランジ，マンホール，弁グランド部などの漏
えい故障をさし，ドレン管などにクラックが入った故障， あるいは弁体が破損したといった故障は含んでいない。 それらはそれぞれ管破孔，部品破損という事象に分類さ れている. 図で振動之いう項目が事象(結果), 原因の両 側にあるが，それは次のような意味である。すなおち， たとえば図でボイラ系付着品の事象で振動が 1 件あるが,
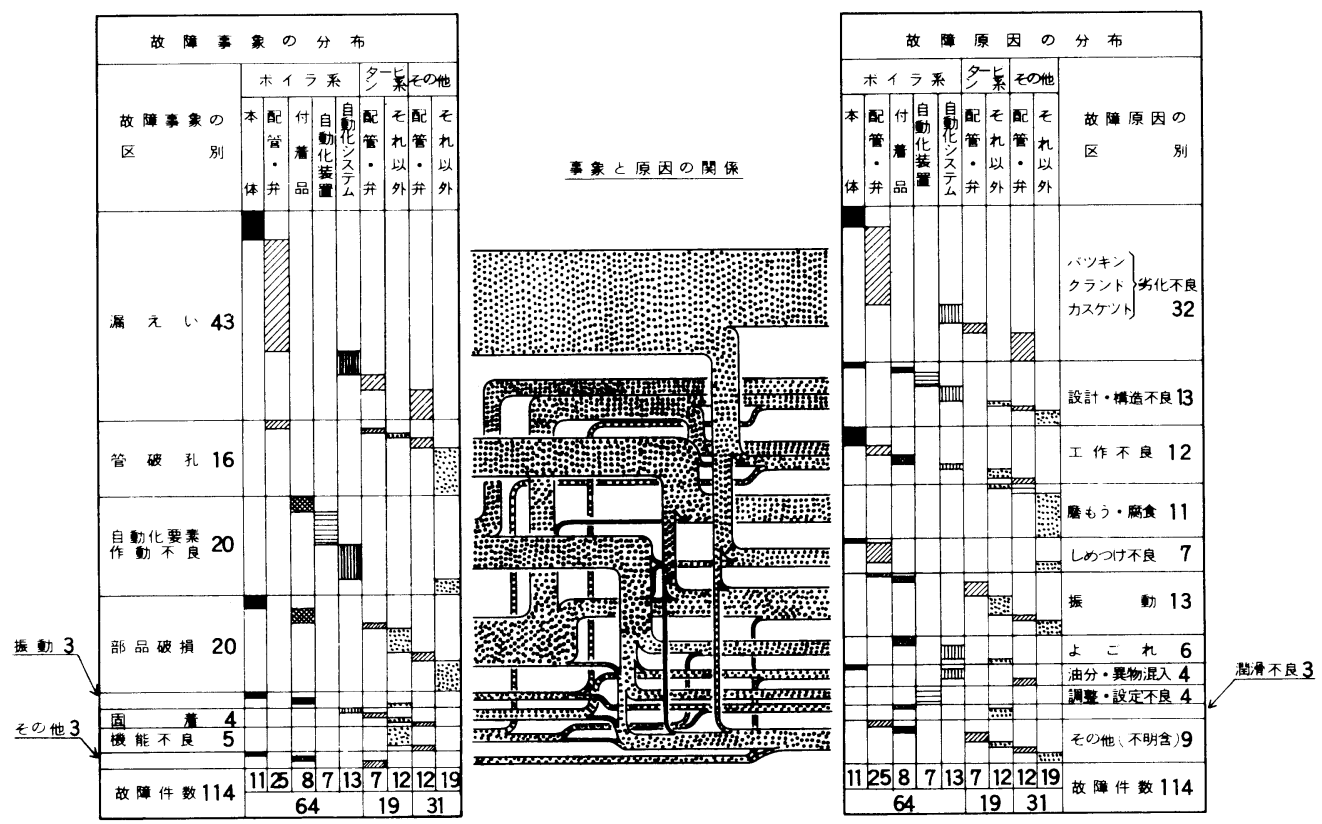

図 5 重大故障の事象と原因の内訳とその関係 
これはGAH入口ダンパの固定スクリュが脱落してダンパ が振動を起こしたという故障であり，したがって，事象 は振動, 原因は設計・構造不良という項目に分類されて いるといった次第である.

まず，故障事象についてみよう．漏えいが 43 件と圧 倒的に多く, ついで管破孔, 自動化要素作動不良, 部品 破損がみられ，てれら 4 事象で 99 件と大部分を占める. 管 破孔や弁体破損(部品破損)などでもそれによって蒸気が 漏れたりしたものであるから，乙れらあ含めると広い意 味での漏えいは49件(43\%)にのぼる. 橋本ら ${ }^{2)}(1966$ 乙 ろ就航船)の主ボイラ消火故障の事象では，漏えいが 71.8

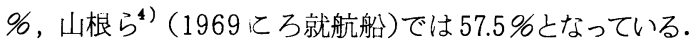
年代を追って減少しており，乙れがMTBFやアベイラビ リティをあげている要因の一つであろうが，しかし，依 然として最も重視すべき故障である. 管破孔がその他の 系統に多いが，乙れは潤滑油クーラの泠却管が破孔した 故障が 1 船に集中して発生したのが 8 件あるためで，乙 れを考慮すると管破孔という故障は一般的には多くない といえる. 発生か所では, 配管・弁が 44 件あって多いが, その大部分は広い意味で漏えいである. 自動化関係では大 部分要素の作動不良である. 自動化システムで漏えいが 5 件 あるが, これらはFWC, STCなどの制御弁に生じている.

一方，故障原因は，パッキン，ガスケットの步化，不 良が多いが，乙れ以外には材質に関係する原因は記録さ れていない，磨粍腐食が 11 件あるが，その大部分は上 述の潤滑油クーラ故障に対するもので，したがって，一 般的には摩耗腐食に起因する故障は，船令が小さいとい うことああろうが, 少ないといえる.振動 13 件 (11\%) は橋本ら ${ }^{2)}$ の $25 \%$ よかなり減っている. 13 件中 7 件 はタービン系統で生じているから, タービン系は全体 19 件中 7 件 $37 \%$ が振動が原团ということであり，乙の系 統では振動への対策を重視すべきである.

最後に事象之原因の関係についてみよう．漏えいのほ とんどは当然ながらパッキン，ガスケットの劣化・不良， 工作，締め付けが原因とみられている．管破孔16件か ら潤滑油クーラ故障 8 件を除いた 8 件のうち 4 件は振動 が原因である．それらは圧力計取付枝管やドレン管で生 じているから，てうした枝管系統の振動への配慮が大切 である. 自動化要素, 部品破損は原因が多様で, 目立っ た特徴は指摘できない.

5.2 漏えい故障広い意味の漏えい故障 49 件の 発生箇所の詳細は図 6 のようで, 弁 20 , フランジ 22 件 で大部分を占める. 弁では安全弁, 暖管弁が目につく. 制御弁 6 件はFWC弁 $2, \mathrm{STC}$ 弁 2 , ドレン調整弁 $1, \mathrm{LO}$ 流量調節弁 1 からなっている. フランジではめくら板, ハンドホール管フランジが多い. 台座む合わせると安全 弁関係は6 件にのぼる。

故障原因の詳細を図 7 に示す. 突き合せ面の場合を考 えると, 合せ面の工作精度, 姿勢, パッキン, 締め付け 程度の 4 要因の総合されたものとして密封性能は決まっ

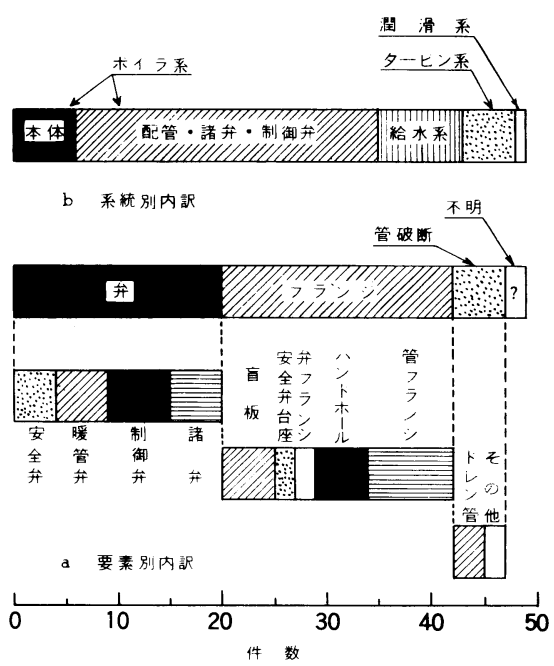

図 6 漏えい重大故障の発生加所

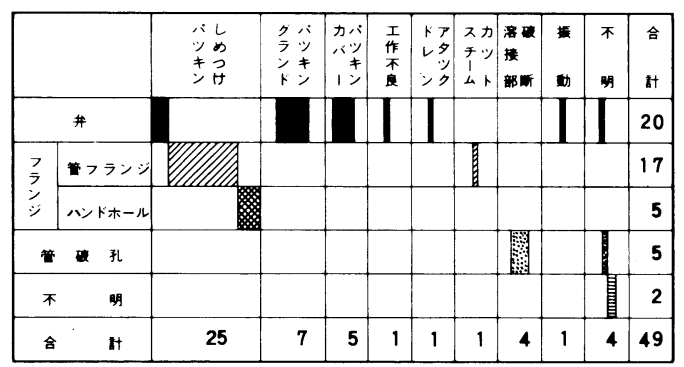

図 7 漏えい重大故障の原因

てくる. 現実に漏れが生じた場合このうちのどれが主原 因であるか特定することは恐らく困難で，回答を分類す ると図のようになるが，図の分類は原因というより，む しろパッキン類を入れかえて締め付け直すととによって 漏れが止った，という復旧事実を反映しているとみるべ きであろう. パッキン類が原因と記録されている故障の 発生時期をみると図8のようになる。記録にはパッキン 劣化とかかれているものが多いが，しかし発生時期をみ ると図のように初期故障的性格が強い.ただし，ハンド ホールの発生時期はかなり後へずれており，性格が異な る. ハンドホールはいったん漏れると重大故障になるこ とが当然予想されるから，当初から設計，工作上の信頼 度が高いからではないかと思われる. そうだとすれば， ハンドホールの故障原因は記録よ゙おりパッキン劣化が主 因々みなせ、ハンドホールの傾向と比較すれば，した がって，管フランジ，弁の漏れの原因として，パッキン 類ももちろん重要であるが，他の要因とくに合せ面の姿 勢や締め付けなどに注目すべきであろう.

パッキン類以外の要冈に対する対策が施され，ハンド ホールのように初期故障が一掃されたとしても, 就航後 


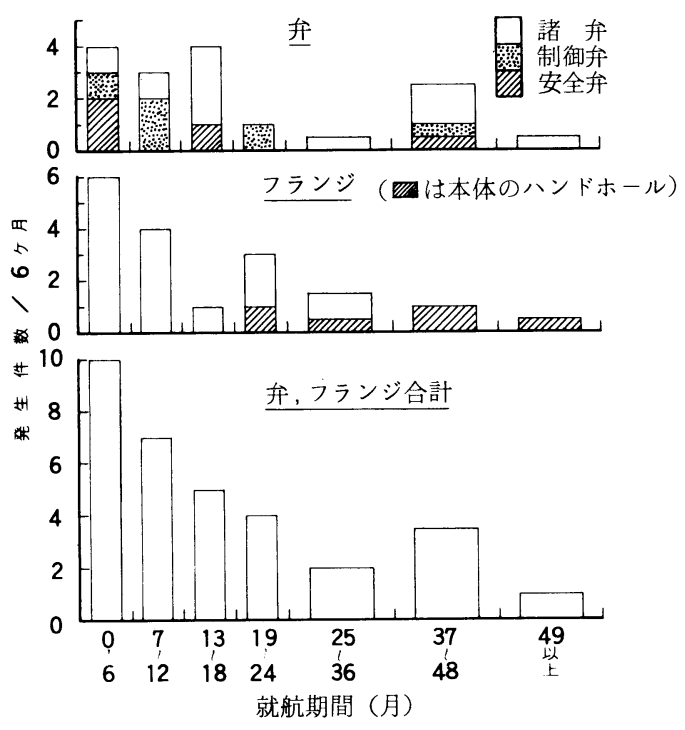

図 8 パッキン類を主因とする漏えい故障発生件数 の就航期間による変化

2 年を過ぎるとハンドホールにも漏れが発生し出してい る事実に注意しなければならない.とのととはパッキン 類の寿命がその程度, つまり，図 8 から判断して 3 年程 度のオーダとみれるからである．以上より，漏えい対策 としては, 既述 4 要因の総合的管理を強化することによ って初期故障を減らすとと，およびパッキン類の寿命が 3 年オーダであることを考慮した就航後のメインテナン スを図ることが必要と思われる.

管破孔による漏れが 5 件あり，うち 4 件までは溶接部 で生じている. しかも，乙れらは先述のように小径の枝 管に生じているので, 乙れら部分の溶接工作への配慮が 必要であろう.

漏えい対策はボイラメーカの方でも不断の努力が払わ れている.たとえば，ハンドホールに関していえば，内 輪つきパッキンの採用のほか，1972，73ころからは， 管栓法の工夫によりハンドホール数を減少させること， だ円形から工作精度のよい丸形へのきりかえ，また，最 近では溶接形ハンドホール，すり合せジグの考案などの 工夫むされつつある．乙うした対策が漏えい故障の減少 に奇与してきたといえるが，漏えい対策はタービン船の 信頼性向上のうえで, 依然最も重要な課題の一つである.

\section{3 ボイラ系の故障〈故障発生箇所の特徵〉} 本体の故障 11 件中 6 件は漏えいでこれはすでに述べた. 残り 5 件は，スキンケーシング焼損破孔という故障 3 件 (これらは同一船同一ボイラで就航直後に生じている), ボイラ水への油分混入, 緩熱器の荒天による振動各 1 件 で，いずれも現時点では特異な故障とみられ，結局，本 体関係ではハンドホールなどの漏えい対策が重要である. 付着品では 8 件中 5 件が $\mathrm{GAH}$ で, 乙れに注目する必要が
ある.自動化システムでは 13 件の故障があるが，ACC， バーナ制御, STC各 1 件で, 残り 10 件はすべて FWC であり，乙れに注目しなければならない。自動化装置 7 件は，スイッチ作動不良 5 件，リレー不良 2 件ですべて 要素故障である. 以上みたとおりボイラ系では漏えい故 障を除くと，GAHとFWCの故障対策が重要といえる.

〈GAH〉 5 件の故障はいずれあ機械的なものである. 内容をみると軸受, 駆動モータに関するあのが 4 件で, これらは故障に至る過程に相異はあるが, 結局は過負荷 （強度不足）が原因とみれる. 舶用ボイラに関するシンポ ジゥム゙)でも，GAHに対して「機械的に丈夫なむのを」 との要望が出されており, 構造工作に関して全体的な検 討が必要といえる.

〈FWC〉 故障内容は表 8 のようである. 給水加減弁 4 件はいずれも漏えいで，氻る重要機器は十分な製作 管理が行われているはずであるが，にあかかわらず，乙 れだけの漏えいがみられる事実は注目されてよい. した がって，故障を前提にしたシステム信頼性をあげる検討 あ必要と思われる. 給水加減弁以外では, 配管系統への 異物混入，パッキンのはみ出しといった工作不良故障 3 件が目につき，まだ固有信頼性をあげる余地のあること を意味している.FWCはいったん故障すると重大故障 になりやすいので, 全体的検討を要請されているシステ ムといえよう.

5.4 タービン系の故障本体, 減速装置の故障 は7件あるが, すべて潤滑, 軸受にかかわるもので内容 はさまざまであるが, 工作不良, 異物混入, よでれが目 立ち，工作上の管理ミスに起因するあのが多いようであ る. 振動が原因の故障は, 潤滑系統のものも含めると 10 件にのぼる. そしてその中には, 軸振動計センサーリー

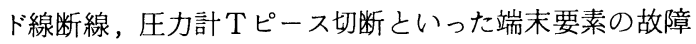
がみられる.タービン系では以上のとおりで, 軸受・潤 滑関係, 振動に起因するもの，および既述の配管，弁の 漏えいの三つが特徴といえる.すでにみたようにタービ ン系故障は規模が大きい.しかし, 故障内容はさ細なもの が多い. したがって, 機能上の重要性とは別に, 信頼性 への影響度という観点からの対策が必要である.

\section{5 自動化要素・回路系統の故障 各系統をみ} ると自動化要素や回路の故障がかなりある。それらをま とめると表 9 のようである. 表によると故障規模は時間 でみると平均 2.4 時間, 特に大きい 20.11 時間のものを除 くと 1.15 時間となり, 規模としては大きくない. しかし 件数では 24 件 $(21 \%)$ を占め, 無視できない. 発生か所 をみるとボイラ系が多く，タービン系ではみられない. 内訳では，機器要素 10 件の中ではスイッチ類が 5 件を 占めるが，いずれあ品質不良である。また，配管（制御 流体回路) の故障 5 件は, シールュア不足によるフレー ムアイのよごれ 2, 制御空気ラインへのLO混入, 配管 工事ミスによる空気量不足, 振動による空気配管切断各 1 件で, いずれも以前から指摘されている故障といえる 
表 8 FWC 故障内容詳細

\begin{tabular}{|c|c|c|c|c|}
\hline 内 & 事 & 原 & 故障時間 & 件 数 \\
\hline 給水加減弁ボンネットより給水漏えい & 漏 え & 工作 不良 & 16 & 1 \\
\hline 給水加減弁グランド漏えい & 漏 えい & パッキン & $1.5,1.5,3$ & 3 \\
\hline 給水加減器作動不良(パイロット弁内污れ) & 作 動 不良 & 工作不良 & 0.17 & 1 \\
\hline ドラムレベルトランスミッタ作動不良タービントリップ & 作動不良 & 調 整不良 & $1.1,1.3$ & 2 \\
\hline サーモスタットコントロール弁不良低水位トリップ & 作動 不良 & 構造不良 & 20 & 1 \\
\hline さびのかみ込みでピストン弁固着 & 固 & 異物 混入 & 9.3 & 1 \\
\hline 空気ラインにLO混入で作動不良 & 作動不良 & 異物混入 & 2 & 1 \\
\hline 計 & - & - & 平均 5.6 & 10 \\
\hline
\end{tabular}

表 9 自動化要素・回路系統故障内容詳細

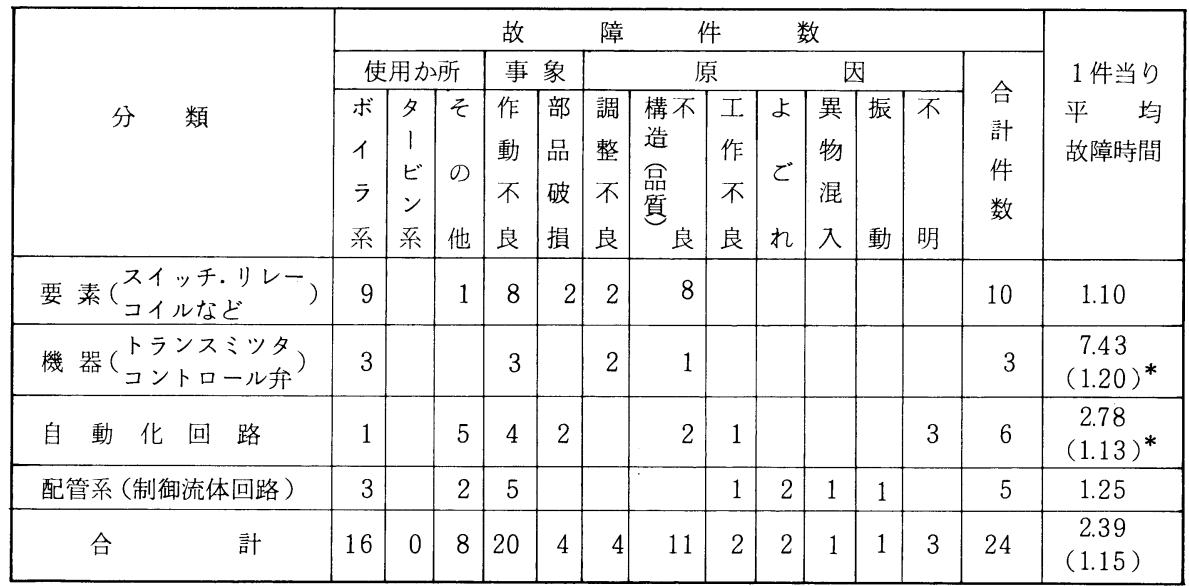

（注） *（）は故障時間のとくに大きい故障 1 件を除いた平均値

が，まだ克服されていない。したがって，乙の系統では， 使用要素 (とくにスイッチ類)の品質管理, 制御流体回路 の検討などが比較的重視すべき点といえよう.

\section{6. 結言}

1972, 73 年の就航船を中心に 4 社 15 隻のタービン船 について, 就航後平均 4 年間の故障記録を収集し, 重大 故障(減速または停止を要した故障)の統計的, 内容的分 析を行った. 明らかになった点は以下のとおりである.

(1)平均故障時間は 9.6 時間で大略指数分布にしたがう. この值は 1966,67 年ころの就航船のデータ ${ }^{1}{ }^{2)}$ の 10.45 , 15.6 時間と比較してやや小さくなっている. MTBFは 3717 時間で, 1966, 67 年ころの就航船のそれ ${ }^{1,2)} 1547$, 1110 時間，また 1969 年ころの就航船 ${ }^{4}$ のそれ〜 1200 時間と比べてかなり大きくなっている. 結果として平均 アベイラビリティも $0.9969^{1)}, 0.9936^{2)} ， 0.995^{4)}$ に対し て 0.9975 とかなりよくなっている.

(2)系統別の発生か所はボイラ系 $56 \%$, タービン系 $17 \%$, その他 $27 \%$, 平均故障時間はそれぞれ 9.0,22, 3.6 時間 である. ボイラ系の比率は過去の二つのいずれのデータ よりも大きくなっている. タービン系は 1 件あたりの故 障時間が長く, かつ, 主機を停止しなければならない故
障が多いので, 件数は多くないが重視する必要がある.

(3)平均修理人数, 時間, 工数はそれぞれ 6.5 人，5.0時 間, 36.1 人・時間で, 以前のそれら ${ }^{1)} 8.34,6.05,57.1$ よ りもいずれも減少している. 修理時間, 工数は大略指数 分布するが，人数はそうはならない.9人以上, つまり 事実上機関関係乗組員のすべてを要した故障が $41 \%$ あ る.

(4)故障内容についてはつぎのことがいえる.

i）故障事象では漏えい故障が最む多く，配管，弁 を中心に系統を問わず発生しており，全体の $43 \%$ を占める. 発生時期から判断する之初期故障的性 格のあのがかなりあるので, 合せ面の姿勢, パッ キン，締め付けなどの総合的管理が必要である.

また，ハンドホールの故障実態から判断するとパ ッキン類の寿命は 3 年オーダと考えられ，乙れを 考慮した保守も大切といえる. 漏えい故障は以前 と比べると次第に減少しつつあるが, 依然として 最も注目すべき故障である。

ii）ボイラ系で重視すべきはGAHとFWCである. GAHは機械的欠陷に起因する故障であり，構造 工作上の検討が必要である. FWCは漏えい対策 と, システム信頼性をあげる工夫が必要である。 
iii）タービン系では軸受, 潤滑関係の工作管理，お よび振動に起因する故障への対策が重要であろう.

iv）自動化要素(とくにスイッチ,リレーなど), 制 御流体回路の故障は全体の $21 \%$ である.これらの 故障の規模は大きくないが, 発生件数としては無 視できない．

なお，今回の分析を行うにあたり，故障データの記録 方法や各種カテゴリーの規格化の必要性が痛感された。 故障データをつみ重ねていくととは今後とあ必要と思わ れるので, 故障調査方法の整備が望まれる.
おわりに，アンケート回答に対して多忙の中を積極的 に御協力頂いた各船会社に，また，故障データの分析に 熱心に参加されたボイラ研究委員会委員各位に深甚な謝 意を表する次第です。

\section{文献}

1）橋本・石塚，船幾誌，6-10 (昭 46-10)，715.

2) 橋本・ほ加 2 名, 舶機誌, 7-8 (昭 47-8)，600.

3）橋本・石塚, 舶機誌, 7-7 (昭 47-7)，529.

4) 山根 ・大原, 舶機誌, 10-2 (昭 50-2)，170.

5）野口・ほか 2 名, 船機構 23 回前刷, (昭 52-10), 151. 